\title{
HARMONISING ACCESSIBILITY IN THE EU SINGLE MARKET: CHALLENGES FOR MAKING THE EUROPEAN ACCESSIBILITY ACT WORK
}

\author{
Anna Drabarz*
}

\begin{abstract}
In the last decade, accessibility has become a buzzword not only among actors of the civil society advocating for the rights of persons with disabilities but also among the legislators in the European Union. The EU has adopted a series of binding regulations aiming at approximating the common understanding of accessibility and Member States' approach to operationalising the right. Being part of EU harmonised law, the European Accessibility Act has already been considered a milestone in the process. The choice of an approach / approaches will decide about a success of its transposition into Member States legal systems.
\end{abstract}

Keywords: standardisation of products and services, EU disability law, CRPD, EU internal market, persons with disabilities

\section{INTRODUCTION: TOWARDS EU ACCESSIBILITY 2.0}

Accessibility brings harmony - this statement of an axiological nature has obtained a new dimension within the recent legislative and standardising works of the European Union. Indeed, the duty of effective enforce-

\footnotetext{
Dr. Anna Drabarz, Assistant Professor, Faculty of Law, International and European Law Department, University of Bialystok; correspondence address: ul. Mickiewicza 1, 15-213 Białystok, Poland; e-mail: a.drabarz@uwb.edu.pl; https://orcid.org/0000-0003-0855-3841.
} 
ment of the right to accessibility provided by the United Nations Convention on the Rights of Persons with Disabilities (CRPD) ${ }^{1}$, for many groups, including persons with disabilities, older people or other individuals with functional limitations, appears as a promise of restoration of the universally accessible order, where no one is excluded from or limited in use of spaces, products and services and everybody is able to equally enjoy all spheres of the common reality. In order to be realised, this promise requires the states parties to design and implement legal and policy constructs operationalising CRPD provisions in a way that are both wholesome and feasible.

As a result of ratifying the CRPD, since January 2011, the EU (now along with its all Member States) has been bound to fulfil the obligations of the Convention within the limits of its competence. The initial report on the implementation of the CRPD by the $\mathrm{EU}^{2}$ showed a range of developments introduced and coordinated by the Union in promoting accessibility. By 2014, the EU had already adopted a number of legal acts harmonising accessibility requirements for goods and services to contribute to completing the EU internal market and opening up possibilities for economic operators to sell their products throughout the $\mathrm{EU}^{3}$ and regulations on the rights of persons with reduced mobility in the area of transport ${ }^{4}$. Despite

1 UN Convention on the Rights of Persons with Disabilities, 13 December 2006, in force 03 May 2008, UN Doc. A/RES/61/106, Annex I.

2 Committee on the Rights of Persons with Disabilities. "Consideration of reports submitted by States parties under article 35 of the Convention. Initial report of States parties due in 2012 European Union”, December 3, 2014, https://documents-dds-ny.un.org/doc/UNDOC/GEN/G14/232/64/PDF/G1423264.pdf. (Access date: 30.04.2020).

3 E.g. Regulation (EC) No. 661/2009 concerns type-approval requirements for the general safety of motor vehicles, their trailers and systems, components and separate technical units intended therefor; Directive $95 / 16 / \mathrm{EC}$ on the approximation of the laws of the Member States relating to lifts refers to the accessibility of lifts, OJ L 200, 31.7.2009, p. 1; Directive 2004/27/EC on the Community code relating to medicinal products for human use requires that the packaging of medicinal products include a label in braille and that the package information leaflet be available, on special request, in formats accessible to visually impaired users, OJ L 213, 7.9.1995, p. 1-31; Directive 2009/45/EC on safety rules and standards for passenger ships obliges Member States to ensure that appropriate measures are taken to enable safe access to passenger ships, OJ L 163/1.

4 See Regulation (EC) No 1371/2007 of the European Parliament and of the Council of 23 October 2007 on rail passengers' rights and obligations, OJ L 315, 3.12.2007, p. 14-41; Regulation (EU) No 1177/2010 of the European Parliament and of the Council 
the steps taken to implement the Convention with regard to accessibility creating broad grounds for its implementation, the status quo presented in the report was subject to criticism. ${ }^{5}$

Since then, the European Commission has continued to use mainly legislative but also other instruments, such as standardisation and public funding, to optimise and mainstream the accessibility of the physical environment, transport and ICT in particular. The legal work includes amendments and extensions to regulations on passenger transportation and built environments, as well as general provisions related to structural funds $s^{6}$, as well as the revision of the Public Procurement Directives with reference to accessibility for persons with disabilities ${ }^{7}$. Solutions for greater accessibility are also introduced in specific measures in the fields of consumer protection, currency and transactions. Now work is also underway

of 24 November 2010 concerning the rights of passengers when travelling by sea and inland waterway and amending Regulation (EC) No 2006/2004, OJ L 334, 17.12.2010, p. 1-16; Regulation (EU) No 181/2011 of the European Parliament and of the Council of 16 February 2011 concerning the rights of passengers in bus and coach transport and amending Regulation (EC) No 2006/2004, OJ L 55, 28.2.2011, p. 1-12.

5 Geert Freyhoff, "EU implementation of disability Convention 'comprehensive but conservative", 2014, https://www.theparliamentmagazine.eu/articles/news/eu-implementation-disability-convention-comprehensive-conservative. (Access date: 30.04 .2020 ).

6 See CPR - Proposal for a Regulation of the European Parliament and of the Council laying down common provisions on the European Regional Development Fund, the European Social Fund Plus, the Cohesion Fund, and the European Maritime and Fisheries Fund and financial rules for those and for the Asylum and Migration Fund, the Internal Security Fund and the Border Management and Visa Instrument, COM/2018/375 final 2018/0196 (COD).

7 By 18 April 2016, EU Member States were obliged to transpose the following three directives into national law: Directive 2014/24/EU of the European Parliament and of the Council of 26 February 2014 on public procurement and repealing Directive 2004/18/ EC, OJ L 94, 28.3.2014: 65-242; Directive 2014/25/EU of the European Parliament and of the Council of 26 February 2014 on procurement by entities operating in the water, energy, transport and postal services sectors and repealing Directive 2004/17/EC, OJ L 094 28.3.2014: 243; Directive 2014/23/EU of the European Parliament and of the Council of 26 February 2014 on the award of concession contracts, OJ L 094 28.3.2014: 1-64. The award criteria provided by them for the most advantageous economic tenders include specific references to accessibility for persons with disabilities and design for all users as part of the quality of a tender. The same requirements become an obligation when drawing up technical specifications for all goods and services intended to be used by the public or staff. 
to promote e-accessibility and use ICT products, services, and applications among groups experiencing functional limitations ${ }^{8}$. Adopted in 2016 the Directive on the accessibility of websites and mobile applications of public sector bodies ${ }^{9}$ supports the Digital Agenda for Europe ${ }^{10}$ as well as the implementation of the CRPD in Member States. While the above-mentioned regulations are technical, importantly the key purpose of the directives and regulations is generally twofold; first, to ensure that all citizens can access products and services and participate in society, and to promote and facilitate accessible developments; and second, to obtain cohesion in the selected areas of production and services performed in Members States and, thus, to remove possible barriers to their cross-border mobility.

The adoption of the European Accessibility Act (EAA) ${ }^{11}$ has marked, so far, the most ambitious of the EU legislative steps towards accessibility. The legal regulation which took over ten years to be shaped entered into force on 28 June 2019 after being delayed and burdened with diverse expectations by different groups of stakeholders ${ }^{12}$, even though there are several ways in which the EAA fell short of expectations of the community of persons with disabilities.

The EAA covers products and services that have been identified as being most important for persons with disabilities while being most likely to

8 More on this, e.g.: Laura Preud'homme, "Droit de l'Union européenne et handicap," Revue de l'Union européenne, no. 579 (2014): 336; Anna Lawson, Mark Priestley, "Potential, principle and pragmatism in concurrent multinational monitoring: disability rights in the European Union," International Journal of Human Rights, no. 17 (2013): 739-757.

9 Directive (EU) 2016/2102 of the European Parliament and of the Council of 26 October 2016 on the accessibility of the websites and mobile applications of public sector bodies, OJ L 327, 2.12.2016, p. 1-15.

${ }^{10}$ Communication from the Commission to the European Parliament, the Council, the European Economic and Social Committee and the Committee of the Regions A Digital Agenda for Europe, COM/2010/0245. For updates on it see European Commission, Digital Agenda for Europe, available at https:/ec.europa.eu/digital-single-market/en/ policies/shaping-digital-single-market. (Access date: 30.04.2020).

11 Directive (EU) 2019/882 of the European Parliament and of the Council of 17 April 2019 on the accessibility requirements for products and services, PE/81/2018/ REV/1, OJ L 151, 7.6.2019, p. 70-115.

12 See, e.g., the resources from the European Disability Forum campaign for adoption of the EAA and positions of disabled persons organisations (DPOs). 
have diverging accessibility requirements across EU countries. The Commission consulted stakeholders and experts on accessibility and took into account the obligations deriving from the CRPD on persons with disabilities. The regulated products and services include: computers and operating systems, payment terminals and certain self-service terminals such as ATMs, ticketing and check-in machines, interactive self-service information terminals, smartphones and other equipment for accessing telecommunication services, TV equipment involving digital television services, e-readers, telephony services, services to access audio visual media services, certain elements of air, bus, rail and water transport services such as websites, mobile services, electronic tickets, information, consumer banking, e-books, e-commerce, answer to emergency calls to the single European number ' 112 '. The EAA applies to products and services entering the market on or after 28 June $2025 . .^{13}$

The directive is to be transposed into national legal orders by 28 June 2022 and, with certain exceptions, Member States must apply the measures from 28 June 2025. As in case of any EU directive, a respective national implementation law will be decisive regarding the scope and methods of enforcing. The EAA obliges EU Member States to design and execute the most efficient legal developments in compliance with the objectives and minimum requirements set in the directive. The quality of this important regulation and the level of harmonisation to be obtained depend on the approaches adopted by each Member State. However, due to the matter of the legislation, there are other crucial factors that may influence the success indicators of the EAA implementation.

13 The scope of services and products it covers is, however, considered very limited. Health care services, education, transport, housing, and household appliances were left out of the EAA and a number of exemptions are made even in case of products and services covered by the Act (e.g. when the service is related to urban, suburban and regional transport or is provided by a microenterprise). Furthermore, requirements concerning the built environment related to the services covered by the EAA are left to the decision of Member States. It is obvious that in the Member States where the need to improve is the greatest the readiness to introduce the obligations in the area will remain low. For more thorough analysis see European Disability Forum analysis of the European Accessibility Act, June 2019. Available at http://www.edf-feph.org/newsroom/news/our-analysis-european-accessibilityact. (Access date: 30.04.2020). 
The objective of this paper is to show the possible challenges of harmonisation of EU law on enforcement of accessibility for people with disabilities whose ultimate achievement is the EAA and to analyse selected conditions for its proper implementation. It presents analysis made by scholars and opinions presented by the stakeholders involved in legislative and enforcement processes, including representatives of potential beneficiaries from the EAA provisions, on the topic and consequently answers the following questions:

1. What approach to accessibility - human rights or from the internal market perspective - may occur more effective within the implementation of the EAA?

2. What other measures may support the harmonisation of accessibility requirements for products and services in the EU?

However, first and foremost, I wish to inspire a multidimensional discussion on different aspects of the ongoing transposition of the EAA in Member States which, by engaging all groups of stakeholders, can have a positive impact on legislative works.

\section{THE SINGLE MARKET PERSPECTIVE IN THE EAA}

In 2013, the ANED analysis utilised by the European Commission in the law-making process for the EAA unveiled a variable picture of European accessibility ${ }^{14}$. The general obligations present in national laws (e.g. non-discrimination law or disability law) frequently place a broad duty of accessibility or reasonable adjustment, while there is greater specificity of accessibility requirements for certain goods and services than for others, and in some countries rather than others. Specific requirements are more likely to exist for services than for goods, for public sector provision than for private sector provision, and for those areas subject to existing EU regulation or standardisation. Another conclusion shows that technical standards are more likely to be voluntary than compulsory, or may refer loosely

14 Academic Network of European Disability experts (ANED), "National accessibility requirements and standards for products and services in the European single market: overview and examples," compiled by M. Priestley, VT/2007/005, January 2013. 
to international guidelines. This picture is further complicated by the existence of different accessibility specifications for similar products or services in different countries, with implications for purchases, sales or distribution across national borders within the EU. Generally, there is also lack of common reference points or guidelines for companies, potential customers or suppliers to identify what constitutes an "accessible" product or service.

Taking into account the state, in the Impact Assessment accompanying the Proposal for a Directive of the European Parliament and of the Council on the approximation of the laws, regulations and administrative provisions of the Member States as regards accessibility requirements for products and service, the European Commission indicated that the general objectives of this initiative were "to improve the functioning of the internal market of specific accessible goods and services, while facilitating the work for industry and serving the needs of consumers, as well as to contribute to the goals of the Europe 2020 Strategy and the European Disability Strategy 2010-2020" and specifically it was designed "to lower barriers to cross-border trade and increase competition in the selected goods and services and in the area of public procurement, as well as to facilitate access by consumers with disabilities to a wider range of competitively priced accessible goods and services". ${ }^{15}$ The European Commission has emphasised that, due to the creation of a single set of accessibility requirements, businesses - in particular SMEs - will benefit from the elimination of barriers caused by a fragmented market enjoying easier cross-border trade. The market costs for companies and Member States due to divergent requirements are estimated at $€ 20$ billion in $2020^{16}$ and the proposed EU action was estimated to reduce it by $45 \%$ to $50 \%{ }^{17}$.

15 European Commission, "Commission Staff Working Document. Impact Assessment. Accompanying the document Proposal for a Directive of the European Parliament and of the Council on the approximation of the laws, regulations and administrative provisions of the Member States as regards accessibility requirements for products and services," SWD/2015/0264 final - 2015/0278 (COD): 5.

16 European Commission, "European Accessibility Act. Improving the Accessibility of Products and Services in the Single Market," https://ec.europa.eu/social/main.jsp?catId=1202. (Access date: 30.04 .2020 ).

17 See European Commission, "Impact assessment accompanying Proposal for a Directive on the approximation of the laws, regulations and administrative provisions of the 
According to the study on the socio-economic impact of new measures to improve accessibility of goods and services for people with disabilities performed in 2015, the potential benefits are expected to be higher than the potential accessibility-related costs for all economic operators ${ }^{18}$.

As stated in the EAA's Preamble, the directive aims to improve the functioning of the internal market for accessible products and services, by removing barriers created by divergent regulations across Member States. Thus, the EAA serves one of the core tasks of the EU within the internal market context - harmonisation and legal convergence. With regard to the EAA's transposition, we deal with this term "harmonisation" understood broadly, encompassing both actual harmonisation, i.e. approximation of laws, and also unification or standardisation. In the context of the interplay between secondary law and free movement provisions, it has to be considered "harmonisation" in its functional sense ${ }^{19}$. The nature of the harmonising legal act usually implies one of the types: directive - actual harmonisation or approximation of laws and regulation - most often the unification or standardisation of laws. Historically, regarding harmonisation within EU consumer law, Member States had to agree on the level of consumer protection awarded through relevant directives. ${ }^{20}$ Due to the fact, harmonisation as a policy technique took different shapes: starting out as a form of standardisation, it was turned into a minimum common denominator (minimum harmonisation), and in more recent times the bar was raised to align all Member States to the same standard (maximum

Member States as regards the accessibility requirements for products and services," Brussels, 2.12.2015, SWD(2015) 264 final.

18 Deloitte, "Study on the socio-economic impact of new measures to improve accessibility of goods and services for people with disabilities. Final Report," 2015, https:// ec.europa.eu/social/BlobServlet?docId=14842\&langId=en. (Access date: 30.04.2020).

19 More on inconsistencies of 'harmonisation': Eva J. Lohse, "The meaning of harmonisation in the context of European Union law - a process in need of definition," in Theory and Practice of Harmonisation, eds. Mads Andenas, and Camilla Baasch Andersen, (Cheltenham: Edward Elgar Publishing Ltd., 2011), 284 et seq.

20 Norbert Reich, "From minimal to full to 'half' harmonisation," in European Consumer Protection: Theory and Practice, eds. James Devenney, and Mel Kenny (Cambridge: Cambridge University Press, 2012), 4, https://doi.org/10.1017/ CBO9781139003452.003. 
harmonisation $)^{21}$. Lately, since about 2000, there is the tendency in EU consumer law towards full harmonisation, under which Member States can choose to increase the scope and intensity of consumer protection which is also the case for the EAA.

Installing accessibility as an element of harmonised legal norms is the only effective way of implementing and enforcing it. However, it is worth considering diverse perspectives on the process of converging the EU internal market. Anthony Giannoumis presents an approach to achieving transnational convergence in the field of digital accessibility, diverging from the existing literature, demonstrating that via a bottom-up approach, public and private sector actors can contribute to convergence of procurement policy in the EU, referring to the international harmonisation or acceptance of common standards and norms, by participating in international policy networks. He states that a bottom-up perspective, emphasising the influence of policy networks on policy design, provides a useful approach for examining convergence and emphasises the crucial role of policy actors in the European Union that participated in the harmonisation of policies and the legal norms and instruments that give these policies their legal effect. ${ }^{22}$

The bottom-up perspective is indispensable in the EAA's transposition as the single market regulated by its provisions concerns a plethora of actors. Now the EU is entering a period where the European Commission will work with experts and the Member States will draft implementation acts and details in the legislation as well as run public consultations. At every stage of transposition and then implementation works all relevant stakeholders of the regulation should be present. The main sector fully in the scope of the EAA is the ICT industry and it appears obvious that ICT consultants should be informed and involved in the standardisation pro-

21 Fernando Gomez, and Juan J. Ganuza, "An Economic Analysis of Harmonization Regimes: Full Harmonization, Minimum Harmonization or Optional Instrument?," European Review of Contract Law, no. 7(2) (2011): 275.

22 Anthony Giannoumis, "Transnational convergence of public procurement policy: a 'bottom-up' analysis of policy networks and the international harmonisation of accessibility standards for information and communication technology," International Review of Law, Computers \& Technology, no. 29 (2015): 2-3, 183-206, https://doi.org/10.1080/136 00869.2015.1055662. 
cess from the very beginning, to provide comments and input throughout the standardisation work, to resolve technical issues and minimise potential delays. The AEE is ambitious in its scope providing that it places demands on accessibility throughout the value chain: manufacturers, authorised representatives, importers and distributors of products and services are affected and insights in their specific perspectives in every Member State are crucial to proper understanding of the conditions of the regulation. Although European harmonised product and service legislation applies directly to manufacturers, importers, providers and suppliers and not directly to end users, it is of significance to the end user. Also, the EAA's provisions take into account needs of different groups of consumers (see in the next section) and it is highly welcome that the EAA directly stipulates that Disabled Persons' Organisations (DPOs) are to work with national authorities, other stakeholders, and the European Commission to advise them during the implementation of the Act and they will also be involved in future reviews of the Act. Other entities that should not be missed in the early preparatory works are national Market Surveillance Authorities with a prominent role in monitoring and controlling products and services provision, as well as NGOs, national authorities or other bodies whose competence in consumer or human rights or practice of accessibility will let them advocate and represent individuals in court under national laws.

At this point, it is worth indicating that the EAA sets provisions which deviate from the spirit of the New Legislative Framework (NLF) ${ }^{23}$. Adopted by the European Council in 2008, the NLF provided a framework serving as a template for future regulations based on the principle that presumption of conformity of products and services to the EU legislation which may be demonstrated through compliance with harmonised European standards. This is the most common and reliable approach to conformity assessment with NLF legislation which aims to improve market surveillance, clarify the use of CE marking and establish a common legal framework for industrial products. The EAA also includes the strong NLF elements: inter alia accessibility requirements for the products and

23 European Commission, New legislative framework, https:/ec.europa.eu/growth/ single-market/european-standards/harmonised-standards/new-legislative-framework-andemas_en. (Access date: 30.04.2020). 
services included in the EAA are mandatory for public procurement; for products and services not included in the EAA, it provides a list of accessibility requirements that can help to demonstrate compliance with accessibility provisions laid down in present and future EU laws (e.g. EU funds regulation $\mathrm{s}^{24}$ ); economic operators are obliged to take immediate corrective measures, or withdraw, if a product does not meet the accessibility requirements of the EAA and, if one Member State withdraws an inaccessible product from the market the others must follow suit. However, it sets provisions that may complicate or prevent the adoption of harmonised standards.

Compliant with Article 15 of the EAA, to receive a draft of harmonised standards, the European Commission issues a standardisation request ("mandate") to the European Standards Organisations (ESOs) to ensure that there is a harmonised EN standard that can serve as minimum requirements ${ }^{25}$. While recognising standardisation as means of compliance with the requirements, the EAA's provisions do not ensure that the standardisation process will be carried out effectively. ${ }^{26}$ The Act allows the Commission to release a mandate up to 2 years after the entry into force of the

${ }^{24} \mathrm{CPR}$ recital 5 stresses that the Union law harmonising accessibility requirements for products and services is applicable to EU co-funded investments, hence suggesting that the EAA is applicable when investing EU funds. The Commission's proposal for the Common Provisions Regulation for the period 2021-2027 has been amended by co-legislators with an article 6a explicitly stating in point 3 "Member States and the Commission shall take appropriate steps to prevent any discrimination based on gender, racial or ethnic origin, religion or belief, disability, age or sexual orientation during the preparation, implementation, monitoring, reporting and evaluation of programmes. In particular, accessibility for persons with disabilities shall be taken into account throughout the preparation and implementation of programmes." The CPR proposal also includes the horizontal enabling conditions on the effective application and implementation of the EU Charter of Fundamental Rights and of the UNCRPD, which should be assessed throughout the implementation period of the 2021-2027 Funds.

25 It is considered likely that the regulations will build on EN 301 549. See Standard - EN 301549 "Accessibility requirements suitable for public procurement of ICT products and services in Europe". Available at https://www.etsi.org/deliver/etsi_en/301500_301599 1301549/02.01.02_60/en_301549v020102p.pdf. (Access date: 30.04.2020).

26 DIGITALEUROPE, "Standardisation is key to the success of the European Accessibility Act," https://www.digitaleurope.org/resources/standardisation-is-key-to-the-success -of-the-european-accessibility-act (Access date: 30.04.2020). 
Directive, up until June 2021, which greatly reduces the time remaining for ESOs to draft the standards in collaboration with all Member States and stakeholders - which is especially important for legislation as complex as the EAA. According to announcements within the EAA National Contact Points' Ad Hoc Group, the Commission was supposed to release the mandate within 6 months after the publication of the EAA in the beginning of 2020 (none has been issued by May 2020), so standards would be available when the accessibility requirements enter into force in 2025 . If the option to demonstrate compliance through the familiar route of harmonised standards was unavailable, it could disturb the implementation of the EAA as companies, authorities and consumers are hindered without the valuable reference point of a harmonised standard.

Moreover, the EAA states that in case of "undue delays" in the standardisation procedure, the European Commission may withdraw the mandate and draft mandatory technical specifications that meet the Annex II criteria of Regulation 1025/2012 on European standardisation ${ }^{27}$, instead of harmonised standards. However, there is no process mentioned to identify such technical specifications and the Act waives the requirement that these technical specifications be developed by a non-profit organisation. it means that these technical specifications would be developed outside the well-established governance system set in place to develop European Standards and may be incompatible with the code of good practice for the preparation, adoption and application of standards within the World Trade Organisation Technical Barriers to Trade Agreement ${ }^{28}$.

Additionally, the vagueness of the used term "undue delays" will lead to high uncertainty for ESOs and industry. In the EAA, a recital ( $\left.\mathrm{n}^{\circ} 76\right)$ also states that an "undue delay" may happen if the Commission does

27 Regulation (EU) No 1025/2012 of the European Parliament and of the Council of 25 October 2012 on European standardisation, amending Council Directives 89/686/ EEC and 93/15/EEC and Directives 94/9/EC, 94/25/EC, 95/16/EC, 97/23/EC, 98/34/ EC, 2004/22/EC, 2007/23/EC, 2009/23/EC and 2009/105/EC of the European Parliament and of the Council and repealing Council Decision 87/95/EEC and Decision No 1673/2006/EC of the European Parliament and of the Council, OJ L 316, 14.11.2012: $12-33$.

28 WTO, Agreement on Technical Barriers to Trade, 1995, https://www.wto.org/english/docs_e/legal_e/17-tbt_e.htm. (Access date: 30.04.2020). 
not publish a reference to a harmonised standard because it considers that the draft standard does not satisfy the requirements which it was supposed to cover. This means that an "undue delay" may be two-fold: an unspecified lateness in the process or a lack of quality of the draft standard. This would be also the case if the Commission decides to withdraw the mandate and to draft technical specifications which would prove unfit for the industry due to a lack of concertation with all stakeholders - which, as underlined before, is of essential importance in the implementation of the EAA.

\section{THE HUMAN RIGHTS PERSPECTIVE IN THE EAA}

Within the European Disability Strategy 2010-2020, evoked in the EAA, the key commitment is to "Ensure accessibility to goods, services including public services and assistive devices for people with disabilities' and making progress on this issue at the European level is seen as a 'precondition for participation in society and in the economy." 29 As a document prior to the ratification of the CRPD by the EU and to most of legal developments on accessibility in EU law, it did not refer to specific acts, however, it remains in line with the progress made later on in the area. The EAA refers to the CRPD in its preamble stating that the Act aims to facilitate the implementation of the Convention by establishing common Union rules. However, the EU actions go further - the EAA supports Member States' efforts to harmonise implementation of national obligations as well as accessibility obligations under the CRPD. ${ }^{30}$

In this context, it is worth emphasising that the right of accessibility is a complex construct of an unprecedented nature. In the entire text of the CRPD, there is no reference to an actual "right" to accessibility. During the negotiation sessions leading to the adoption of the CRPD, concerns were demonstrated regarding the fact that accessibility was framed as a general principle and a state obligation, and not as a right to accessible environ-

29 "European Disability Strategy 2010-2020: A Renewed Commitment to a BarrierFree Europe," COM (2010) 636.

30 Recital No 16 of the EAA's Preamble. 
ments and services on an equal basis with others. ${ }^{31}$ Supporting the latter, Ron McCallum, the former Chair of the CRPD Committee, expressed the significance of accessibility commenting that there is nothing "more crucial for persons with disabilities than accessibility" 32 . However, recently scholars recognise without questioning that Article 9 of the CRPD as an innovative provision formulates, for the first time in a UN human rights agreement, a right to accessibility ${ }^{33}$ and it "adds considerable content" to the concept of accessibility ${ }^{34}$. Andrea Broderick argues that the CRPD has created self-standing rights, not previously seen in binding international human rights treaty law - among them the right to accessibility ${ }^{35}$.

Such a situation has far-reaching implications in the scope of States Parties' domestic legal frameworks. In its General Comment 5 on persons with disabilities the UN Committee on Economic, Social and Cultural Rights has acknowledged: "The obligation in the case of such a vulnerable and disadvantaged group [as persons with disabilities]' is to take positive action to reduce structural disadvantages and to give appropriate preferential treatment to people with disabilities [...]. This almost invariably means that additional resources will need to be made available for this purpose and that a wide range of specially tailored measures will be required" 36 . Nevertheless, the exact parameters of that right to accessibility,

31 "7th Session of the Ad Hoc Committee", Volume 8(2), 17 January 2006.

32 Janet Lord, Accessibility and Human Rights Fusion in the CRPD: Assessing the Scope and Content of the Accessibility Principle and Duty under the CRPD. Geneva: United Nations Committee on the Rights of Persons with Disabilities, 2010: 1.

33 See, e.g., Marianne Schulze, Understanding the UN Convention on the rights of persons with disabilities (New York: Handicap International, Professional Publications Unit, 2010), 52; Frédéric Mégret, "The disabilities Convention: towards a holistic concept of rights," International Journal of Human Rights, no. 12 (2008): 261-278.

34 Janet Lord, and Michael Stein, "Charting the Development of Human Rights Law through the CRPD," in The United Nations Convention on the Rights of Persons with Disabilities: A Commentary, ed. Valentina Della Fina, Rachele Cera, and Giuseppe Palmisano (Cham: Springer, 2017), 732.

35 Andrea Broderick, "Of rights and obligations: the birth of accessibility," International Journal of Human Rights, no. 4 (2019): 14, https://doi.org/10.1080/13642987.201 9.1634556 .

36 Committee on Economic, Social and Cultural Rights, General comment 5 on persons with disabilities, E/1995/22, para. 9. 
which should remain distinguished from the right to access, have not been clearly defined nor have they been properly tested to date.

At the same time, the inclusion of the principle of accessibility within a binding human rights treaty constitutes a novel addition to the international human rights law regime. DPOs and disability rights advocates used to present the need for ensuring accessibility from the human rights standpoint which became strengthened with the adoption of the CRPD and consolidated by its ratification by the EU and all Member States. Also the CRPD Committee's General Comment No. 2 suggests that and "accessibility should be viewed as a disability-specific reaffirmation of the social aspect of the right to access ${ }^{\prime 37}$, established by earlier adopted UN human rights treaties ${ }^{38}$. The approach reserving the right to accessibility to the group of persons with disabilities should be, however, challenged.

Accessibility is treated as a group right of a collective nature. The CRPD Committee has elaborated on the group dimension of accessibility, stating that it is "an ex ante duty" and indicating that: "Accessibility is related to groups, whereas reasonable accommodation is related to individuals". States Parties therefore "have the duty to provide accessibility before receiving an individual request to enter or use a place or service" ${ }^{39}$. In the context of the access to products and services the human right to accessibility in most cases fits in the sphere of consumer rights. ${ }^{40}$ The EAA gives grounds

37 Committee on the Rights of Persons with Disabilities (2014), General Comment 2 on Accessibility, CRPD/C/GC/2, para. 4.

38 The CRPD Committee referred to Article 5(f) of the International Convention on the Elimination of All Forms of Racial Discrimination, which guarantees everyone equality before the law in the enjoyment of the right of access to any place or service intended for use by the general public, such as transport, hotels, restaurants, cafes, theatres and parks, stating that "a precedent has been established in the international human rights legal framework for viewing the right to access as a right per se". See Committee on the Rights of Persons with Disabilities (2014), para. 3.

39 Ibidem, para. 25.

40 In academic circles, opinions on the appropriateness of elevating consumer rights to the level of human rights are divided. In the light of the complexities of products and services brought about by advancement in technology, globalisation and increasing roles of multinational corporations in trade, it is argued that there is need to elevate of consumer rights to human rights, nationally and internationally. See Festus Okechukwu Ukwueze, "Towards a new consumer rights paradigm: Elevating consumer rights to human rights in 
to the concept as, despite referring to the CRPD and limitations resulting from disability, it points to persons with functional limitations as the provisions' beneficiaries. In sentence 2 in recital No 4 of the Preamble it explains: "The concept of 'persons with functional limitations', as referred to in this Directive, includes persons who have any physical, mental, intellectual or sensory impairments, age related impairments, or other human body performance related causes, permanent or temporary, which, in interaction with various barriers, result in their reduced access to products and services, leading to a situation that requires those products and services to be adapted to their particular needs." The scope of persons protected by the EAA is then wider, not restricted to persons with disabilities, and include anybody who could benefit from accessibility due to functional limitations. Still we talk here about occurrence of some objective "limitations" hindering the access, not preferences in using of products and services. However, the EAA accentuates particular needs of individuals, which may in further developments shift the nature of the right of accessibility. It brings it closer to human rights which an individual has for the sole reason of being a member of humankind and whose objects are of the greatest importance. Nonetheless, collective group rights are rights possessed by individuals belonging to a group distinguished by a characteristic and can be exercised in collective and individual form. ${ }^{41}$ In the case of the right to accessibility provided in the EAA, such an approach is too limiting for interpretation of the EAA and seems recently under deconstruction in EU law.

Another interesting aspect of the right to accessibility concerns the scope of the duty bearers. Article 9 of the CRPD enshrines a broad concept of access that covers both public and private actors as it is applicable to all kinds of actors which make their services or products "open or provided to the public". Thus, its provision places a specific burden on private and public actors regarding information and communication technologies (ICT), including the Internet ${ }^{42}$. It shifts the emphasis from the public or

South Africa," South African Journal on Human Rights, Volume 32, Issue 2(2016): 248-271, DOI: 10.1080/02587203.2016.1215655.

${ }^{41}$ More in Wiktor Osiatyński, Human Rights and Their Limits (Cambridge and New York: Cambridge University Press, 2009).

42 Marianne Schulze, Understanding the UN Convention on the rights of persons with disabilities, 52 . 
private nature of products, services and information and communication to the aimed scope of their recipients. As long as products and services are supplied to the public, they must be accessible to all, regardless of whether they are provided by a private company or a public authority. The elimination of this differentiation between public and private is unprecedented - earlier rules placed the requirements for accessible products and services only on government entities or publicly funded enterprises operating for the public good and, thus, obliged to be universally accessible to the public audience. The CRPD Committee indicates the need for "proactive engagement of the duty-bearers" 43 by stating that "the right to access for persons with disabilities is ensured through strict implementation of accessibility standards" ${ }^{4}$. Thus, its provision places a specific burden on private and public actors regarding information and communication technologies (ICT), including the Internet ${ }^{45}$. A similar approach is adopted in the EAA. However, whereas the scope is somewhat limited in relation to private entities in para. 2 (b) of Article 9, necessitating only "private entities that offer facilities and services which are open or provided to the public take into account all aspects of accessibility for persons with disabilities", the EAA covers both public and private producers and service providers. Placing accessibility requirements on both public entities and private industry sets the tone for the accomplishment of such standards by the EU and Member States.

\section{CONCLUSIONS}

By defining in the EAA common EU accessibility requirements for selected goods and services and using the same requirements for public procurement, and by improving enforcement of accessibility requirements, the EU has been addressing both economic and social values. The

43 Gian M. Greco, "On Accessibility as a Human Right, with an Application to Media Accessibility," in Researching Audio Description. New Approaches, eds. Anna Matamala, Pilar Orero (London: Palgrave Macmillan 2016), 22.

44 Committee on the Rights of Persons with Disabilities (2014), para. 14.

45 Marianne Schulze, Understanding the UN Convention on the rights of persons with disabilities, 52. 
benefits from the EAA implementation mentioned in its Preamble refer to businesses by indicating their costs reduction, easier cross-border trading and more market opportunities for their accessible products and services, as well as to persons with disabilities and other persons who experience functional limitations by more accessible products and services in the market at more competitive prices, fewer barriers when accessing transport, education and the open labour market and more jobs available where accessibility expertise is needed.

Research on accessibility of products and services is often perceived as relating to the issue of disability rights, not more widely to consumer or human rights. In the transposition of the EAA, it can be beneficial to adopt the vast human rights basis to enable a better understanding of potential functional limitations in a variety of users' practices and behaviour. Using the concept of disability as a gauge of the success in providing accessibility of products and services is the first step to making the common market truly common and responding to basic human needs and realising fundamental rights. To achieve the effect, the involvement of disability movements (including DPOs and self-advocates), senior organisations, citizen movements and IT and service design experts - as well as human rights practitioners - is essential, as their participation in the law-making and policy-making process will ensure adequacy and efficiency of the envisaged change. Moreover, in such a way, acknowledgement of accessibility as a ready to be operationalised principle would let cover all consumers by the EAA's provisions.

I concur with Gian Maria Greco's view that such an approach could "bring it to the forefront of the global policy discussion on nearly all human rights, and in a more universal sense" and "it would also provide a decisive basis towards the full acknowledgement of accessibility studies as a unique and autonomous discipline, comprising its own specific topics, models and methods". ${ }^{46}$

At the same time, the human rights validation seems to be insufficient when it comes to enforcing domestic laws and policies. Introducing and ensuring accessibility in all the areas of socio-economic performance of a state, both in its public and private sectors, constitutes a huge workload

46 Gian M. Greco, op. cit., 33. 
consuming resources of all kinds - expertise, money, time and people's involvement and creativity (just to name the most basic ones). Horizontal, as well as specific amendments to be made in policies and legal regulations often touch and transform relations which have been traditionally designed as inaccessible for centuries. Combining the approach with the instruments available to the EU within the framework of harmonisation of law will contribute to strengthening the basis for as full as possible implementation of accessibility for all citizens of Member States.

\section{REFERENCES}

Broderick, Andrea. "Of rights and obligations: the birth of accessibility." International Journal of Human Rights 2019: 14. https://doi.org/10.1080/1364298 7.2019.1634556.

Giannoumis, Anthony. "Transnational convergence of public procurement policy: a 'bottom-up' analysis of policy networks and the international harmonisation of accessibility standards for information and communication technology." International Review of Law, Computers \& Technology, no. 29(2015): 2-3, 183-206. https://doi.org/10.1080/13600869.2015.1055662.

Gomez, Fernando, Juan Jose Ganuza. "An Economic Analysis of Harmonization Regimes: Full Harmonization, Minimum Harmonization or Optional Instrument?." European Review of Contract Law, no. 7(2)( 2011): 275.

Greco, Gian Maria. "On Accessibility as a Human Right, with an Application to Media Accessibility." In Researching Audio Description. New Approaches, edited by Anna Matamala, and Pilar Orero, 11-33. London: Palgrave Macmillan, 2016.

Lawson, Anna, Mark Priestley. "Potential, principle and pragmatism in concurrent multinational monitoring: disability rights in the European Union." International Journal of Human Rights, no. 17(2013): 739-757.

Lohse, Eva J. "The meaning of harmonisation in the context of European Union law - a process in need of definition." In Theory and Practice of Harmonisation, edited by Mads Andenas, Camilla Baasch Andersen, 282-313. Cheltenham: Edward Elgar Publishing Ltd., 2011.

Lord, Janet E. Accessibility and Human Rights Fusion in the CRPD: Assessing the Scope and Content of the Accessibility Principle and Duty under the CRPD. Geneva: United Nations Committee on the Rights of Persons with Disabilities, 2010. 
Lord, Janet E., Michael Ashley Stein. "Charting the Development of Human Rights Law through the CRPD." In The United Nations Convention on the Rights of Persons with Disabilities: A Commentary, edited by Valentina Della Fina, Rachele Cera and Giuseppe Palmisano, 731-748. Cham: Springer 2017. Mégret, Frédéric, "The disabilities Convention: towards a holistic concept of rights." International Journal of Human Rights, no. 12(2008): 261-278.

Osiatyński, Wiktor. Human Rights and Their Limits. Cambridge and New York: Cambridge University Press, 2009.

Preud'homme, Laura. "Droit de l'Union européenne et handicap." Revue de l'Union européenne, no. 579(2014): 336.

Reich, Norbert. "From minimal to full to 'half' harmonisation." In: European Consumer Protection: Theory and Practice, edited by James Devenney, and Mel Kenny, 3-5. Cambridge: Cambridge University Press, 2012. https://doi. org/10.1017/CBO9781139003452.003.

Schulze, Marianne. Understanding the UN Convention on the rights of persons with disabilities. New York: Handicap International, Professional Publications Unit, 2007. 